\title{
Javanese Nick Name System
}

\author{
I Dewa Putu Wijana
}

Faculty of Cultural Sciences Gadjah Mada University

Email:putu.wijana@ugm.ac.id

\begin{abstract}
This paper aims at describing nick names used in the Javanese community. The research is focused on types of relationships between the nick names and the real names or the physical, mental, and behavioural characteristics of the person they refer to, various referents and their possible relations with the owners of the nickname. By analyzing data of nick names found in Yogyakarta state and its environs, it is found that there are at least four types of relationships that hold between the nick names and the real names or the characteristics of the owner's nick names. Those are arbitrary, formal, semantic, and similarity relation types. The nick names have various referents (trade tool, house utensil, and others; shadow puppet and traditional performance art characters; artists and film characters; animal, its state, and excrement; supernatural creature; profession; food; plant and its seed; Arabian names; traditional play and country) which are related or ironically related with physical, mental, and behavioural characteristics and conditions of the person to whom the nick names are intended to.
\end{abstract}

Keywords: nick name, real name, referent, and relation.

\section{INTRODUCTION}

Javanese people, either who live in urban as well as ones in rural areas generally own nick names. Even, this kind of name can be more popular than the real or formal one. For instance, in many cases, it often happens that someone's formal names are not recognized by the neighbours because on nonformal occasions they are not commonly called by the real names, but by their nick names. According to Hornby [1], nick name is an informal, often humorous, name for a person that is connected with their real name, their personality or appearance, or something they have done. Despite their main function to insult people to whom the nick names are intended, the use of them can also be exploited to indicate the degree of intimacy between the interlocutors. Among people who are already familiar with each other, the use of nick names is considered very common. Additionally, on many occasions, nick names can function to specify someone's formal name in the case that the formal name is owned by more than one or many people. For example, the nickname Gendhon 'big headed catepillar' in Hardjo Gendhon is functions to specify its head because more than one or many people name Hardjo. Pego 'meaningless proper name' is used to modify Suranto in Suranto Pego for giving specification because the head element Suranto 'person born in the month of Sura' is possessed by more than one or many people in that place. Because the formal name Darmo 'truth, obligation' is shared by many individuals, it is extended with Gundhul 'shaved head' concerning the hair style he used to wear.

This paper will try to address some interesting matters concerning the use of nick names in Javanese, one of the biggest local languages in Indonesia. The discussion will focus on the relation types of the nick names and the formal name or the characteristics of the person who owned the name, and the referents exploited by the Javanese in creating nick names and similarity basis underlying between the referents and the characteristics of person referred to by the nick names.

\section{LITERATURE PREVIEW}

Personal names are commonly studied to the use of address terms, as shown by Evan-Pritchard [2] about the Nilotic Nuer in Sudan, Ervin Tripp [3] concerning the rule of address in English, and Suhardi et als. [4] about phonological, syntactic, 
semantic, and collocative characteristics of Javanese address terms. Meanwhile, in a narrower scope, Javanese personal name has also been seriously studied by many scholars. The most important study about this matter is Uhlenbeck's [20] discussion in one of his important books "Kajian Morfologi Bahasa Jawa" (Study on Javanese Morphology) (1982, 3773999). In the last chapter entitled "Ciri-ciri Sistematis Nama Orang dalam Bahasa Jawa" (Systematic Features of Javanese Personal Names), he classifies Javanese personal name into six types. Based on sex, he differentiates between male name (M) and female name $(\mathrm{F}) . \mathrm{M}$ and $\mathrm{F}$ are the further distinctions between Low Class (L) and unmarked class which unspecifically indicate to which class the name owners belong. And, especially for M, the distinction is also made between the first name (small name) which is given before grown-up, and the second name (old name) after the male person grows up. So, completely there are FL (low-class female name), F (unspecific class female name), M1L (low-class male first name), M1 (unspecific class Male first name), M2L (low class male second name) and M2 (unspecific class male second name). Each category has its own specific phonological or lexical characteristics. For example, FL names commonly end with --em and -en in which the vowel of the penults is always [i]: Ardinem, Sajinem, Waginem, Daliyem, Juminten etc. Meanwhile, unmotivated ML names end with -an or -in, and sometimes with -un, such as Siman, Jiman, Sidin, Jidin, Dirun, etc. Motivated names of low-class males are mostly taken from calendar terms, such as Akad 'Sunday', Kemis 'Thursday', Setu 'Saturday', etc. Due to the scope of my study, I will not go into detail about this matter. In short, all have been done by Uhlenbeck [20] concerned with names of Javanese people in more ancient times which are very different from the ones found recently. In Addition, he did not distinguish between real or formal names and nick names because puppet character names like Limbuk, Cangik, Bagong, Semar, etc. are not formal names but nick names. Meanwhile, Widodo [5], [6], discusses the forms, meanings, referents, and functions of Javanese names. The Javanese construction personal names can morphologically be differentiated into two categories, namely monomorphemic basic names, such as Sakur, Wito, Winih, Suka, etc., and polymorphemic complex names, in case the monomorphemic name have undergone various morphological processes, such as Darmadi (Darma + adi), Sudarma (Su- + Darma), Sudarmini (Su- + darma +- -ni), etc. Further, without any clear linguistic concept, he classifies the forms of Javanese name into two types, i.e name that consists of the meaningless element, such as Ninik, Nunuk,
Bambang, Tatik, etc., and one that created from meaningful expressions, such as Teguh 'firm', Sakti 'powerful', Isnin 'second', and Putra 'son'. From a semantic viewpoint, the Javanese names denote various kinds of referents, such as nature: Buwono 'universe', Tirto 'water', Bayu 'wind', Lintang 'star', etc., shadow puppet characters, such as Bima' the second oldest of five Pandawa', Yusdhitira 'the oldest of five Pandawa', Wisnu 'name of Hindu goddess', Baruna 'Hindu sea goddess', etc., body parts, such as Angga 'body', Pada 'feet', Hasta 'hands', Driya 'heart', etc., physical states, such as Kuat 'strong', Prakosa 'strong', Kukuh 'firm', etc., mental states, such as Bagiya 'happy, Ria 'delight (literary style)', Suka ' joyful', etc., and skilfulness, such as Wasis 'clever', Berliandi 'bright diamond', Ajar 'clever', etc. Finally, he implicatively concludes that Javanese names are a cultural identity that should be preserved to strengthen ethnic-cultural characters. In a line with Widodo [5], Sahayu [7] discusses Javanese personal names in terms of forms, semantic features, language shifting, and its comparison with the Germanic names. With regards to its form, Javanese personal names can be classified into monomorphemic words, such as Parjo 'great', Kartika 'star', karta 'prosperous', etc., polymorphemic words, such as Hartawan (Harta + wan) 'rich person', Restuwati (Restu + -wati) 'blessed woman', Legiman (Legi +-man) 'male person born in the first Javanese market day', etc., and phrase, such as Adi Raharjo 'great wealth', Puji Widodo 'blessed to be prosperous', Rizka Pebriana Sarastri 'healthy woman full of luck born in February', etc. So, semantically, the names can be associated with many kinds of referents, such as event, public figure, place, birth order, birth date, etc. There are also various shiftings regarding the language used to create personal names from Old Javanese, New Javanese, and foreign languages, such as Arabic, English, and others. Finally, the Javanese names have significant similarities and differences concerning the referents and their creation motives. What have been discussed by Uchlenbeck, Widodo, and Sahayu are mostly if not all related to real or formal personal names. This paper will discuss a different kind of name, namely nick name which is created under very different motivations compared to the real names. Accordingly, these two types of name have significat differences either in terms of forms, referents, social functions, or motivations underlying their creations.

Comprehensive studies on nick names have been carried out by many scholars, such as Pyton [8] and Starks et als. [9]. Pyton's study classifies three kinds of nikc names, i.e name-based nick name (based 
around addressee's given and surname), addresseebased nick name (based on attributes of the addressee), and event-based nick name (based on a significant incident in the personal life). Meanwhile, Starks et al. [9] studies about nick names used among students in Australian secondary schools. By using data drawn from 4 secondary schools in Queensland, and 1 in Victoria state, the nick names are classified into 4 categories to seek the proportion of each category and students attitudes towards the nick names either as others or their own. They conclude that nick names based on real names which are most frequently found tend to be viewed positively by their owners and their acquaintances. Meanwhile, ones that are derived from physical appearance and backgrounds were viewed ambivalently. The use of this type of nick names will decrease but not eliminate. Finally, the study carried out by Zaitzow et [10] on nick names of female prisoners in midwestern states found that most of $(60 \%)$ inmate respondents have nick names which are mostly given by family members and friends. Only a small number of them came from prison setting. Most of the women liked their nick name received before entering prison, and $22 \%$ of them also received nick names during incarceration, and only $10 \%$ did not like their nick name. Most female felon nick names sources relate to physical characteristics, behavioural characteristics, play on given name, and after another people nick names, and others.

With regards to Javanese nick names, in his article entitled "Dinamika Bentuk-Bentuk Sapaan Sebagai Refleksi Sikap Berbahasa Masyarakat Indonesia" (Adress Terms' Dynamics as a Reflection of The Indonesian Linguistic Attitude), Wibowo \& Retnaningsih [11] only mentions the use of three linguistic forms borrowed from Javanese Nick names, Gendut 'fat', Bencong 'effeminate', and Jembluk 'big' as part of Indonesian Address Terms without further consideration. Supardo [12], as part of the addressing system, only found 3 kinds of nick name referent used for greeting interlocutors, i.e. animal, puppet character, and house utensil without any effort to study it more deeply. Finally, Sulistyowati [13], because of her limited study scope, does not find any nick names in the alternate use of address terms among the Javanese members living in Yogyakarta palace. This study will hopefully inspire other linguists to deepen the Javanese nick names or investigate the use of nick names existing in other local languages in Indonesia and other languages as well.

\section{THEORETICAL FRAME WORK}

Although there is the various degree of styles may exist in every language, such as frozen, formal, consultative, casual, and intimate [15], those styles can be simplified into two varieties. Those are formal and informal styles. In a line with this matter, the personal name can also be differentiated into categories, formal name and informal name. A formal name is the real or official name owned by any person and used on a formal occasion. These names appear in identity cards, birth certificates, insurance policies, and other official documents. Different from the formal name, an informal name is one used informal occasion. It is created as an offence or insulation based on formal, semantic, or similarity relation between the real name or physical and behavioural characteristics of the owners. In every language use and linguistic creativity, including naming creation, some extralinguistic factors play their role in determining the result of the creation. One of those extralinguistic factors is the end or goal of language use. The central role played by these factors can be seen in Hyme's SPEAKING mnemonic theory [16] or Leech pragmatic theory in which he states that speech acts are goal-oriented activities [17]; [18]. Based on this theoretical framework, it can be hypothesized that creations of real names are underlined by fundamental differences from those of nick names. Real name creation is always in the hope of good expectation, and the creators usually view the positive side of the expressions by which the names are created. In contrast, nick name creations, for the seek of effective insults and ironies, tend to be associated with the negative connotations of the linguistic expression to the physical, mental, and attitudinal condition of the nick name owners.

\section{METHOD}

Most data presented in this paper are collected from Javanese nick names used in Yogyakarta State and other adjacent regions through non-participatory observation. The data are further classified into several categories according to the existence of formal, semantic, and similarity relations between them and the real names. Interviewing is done to the owner's names as well as to their relatives and close friends relating to the history or the cause of the nick names. Finally, analysis is carried out to find the referents of the nick names and similarity basis that holds between the referents and the physical characteristics, mental condition, and behavior of the nick name owners. Nick names are presented first, followed by the shortened forms and full forms or part of the real names followed by the rest parts 
placed in bracket. All data are presented in orthographical transcription with an initial capital letter.

\section{RELATION TYPES BETWEEN THE NICK NAME AND THE FORMAL NAME OR ITS REFERENTS}

As far as the Javanese nick names are concerned, most of them are composed of one word consisting of two or three syllables. For example Togog 'puppet clown character on the bad side', Celeng 'forrest pig', Cemplon 'sweet cassava fried ball', Tuyul 'small bodily spirit that obtains wealth for its master', Jelitheng 'black in relation with cricket color', etc. In informal speech situations, these words can be shortened by deleting the first (initial) syllable to be Gog, Leng, Plon, Yul, and Theng without changing the internal meaning. Generally, even though not always, nick names are shorter than their formal or real equivalents because the latter may consist of two, three or more parts such as Dwi Rohartatik 'spiritual second daughter', Hermawan Andry Wibowo 'a charismatic and good deed first son', Dian Retno Hapsari 'beautiful jewel light', which are impossible to find in nick names. Concerning their relation to the formal names of the people they refer to, the relation types can be at least distinct into four types. Those are arbitrary relation, formal relation, semantic relation, and similarity relation type. All of these relation types will be discussed in the following sections. It is important to note that in the case of the real names consisting of two or more parts, only the important part of the real names (which has relation to nick name) is considered in the analysis, and the other ones are put in the bracket.

\subsection{Arbitrary Relation Type}

As most commonly found following linguistic form and meaning relation, that no relation holds between the two entities. In other words, the relation of form and its meaning is arbitrary. So as the relation of several Javanese nick names and the formal names of the person it refers to. All nick names belong to this relation types do not have meaning and referent because they are not derived from common words or proper names which formerly have certain meanings or referents in the extralinguistic world. For example Kotrek, Pego, Godhek, Cibik etc. In this matter, there is no semantic relation $[\#>]$ between such names and the formal names Hermawan Andry Wibowo, Suranto, Mardi, and Dwi Rohartatik.

(1) Kotrek \#> Hermawan (Andry Wibowo)
(2) Pego \#> Suranto

(3) Godhek \#> Mardi

(4) Cibik \#> Dwi Rohartatik

Kotrek, Pego, Godhek, and Cibik are lexical items which can not be found in any Javanese Dictionary.

\subsection{Formal Relation Type}

Javanese nick names are often created fully or in part on the formal basis of the official names of the person to whom they refer. For this relation type, there are several patterns used by the Javanese for the nick naming creation. First, the nick name is created by phonological changes (sound substitution) of one or several sounds of the part of the real name, such as shown in (5), (6), and (7) below:

(5) Kening $>$ Wening (Haryanti)

(6) Bambung $>$ Bambang (Dahono)

(7) Gandhos $>$ Gandung (Nurcahyo)

(8) Lanjur $>$ Lanjar

(9) Lasiyuk > Lasiyem

In this case, the resulting nick names can either be meaningless or intentionally created to correspond to referential words which are in a certain sense having negative connotations or at least cacophonous (unpleasant) sounds (Pradopo, [19]). Kening, Lanjur, and Lasiyuk do not have referential meaning, but Gandhos and Bambung do which consecutively mean 'unprestigious food made of cassava and coconut grate' and 'mad, crazy'. The sound substitution can be accompanied by sound addition, such as seen in (10) and (11):

$$
\begin{aligned}
& \text { (10) Nandul > (Eska) } \text { (Sas)nanda } \\
& \text { (11) Ipul > Ipa }
\end{aligned}
$$

Second, the real names are firstly shortened and then followed by various kinds of phonological processes, such as sound substitution with or without final sound addition, as shown (12) to (16) below in which two of them, (15) and (16) are deliberately made identical with common Javanese words. Ciyut means 'narrow' and buto means 'giant'.
(12) Sunir $>$ Sunar $>$ Sunarto
(13) Marjek $>$ Marji > Marjiono
(14) Kadek $>$ Kadi $>$ Sukadi
(15) Ciyut $>$ Siyut $>$ Sihono
(16) Buto $>$ Bud $>$ Budi (Siswanto) 
The shortened formal name with or without sound modification is followed by initial sound or syllabic addition, such as (17) to (21) below, and all of them have lexical meaning Kanthong 'sack', gotri 'pellet', gembrot 'fat', Kenur 'string', Pedhet 'young cow':

(17) Kanthong $>$ anthok $>$ Katiyanto

(18) Gotri $>$ Tri $>$ Tri (Mastoyo)

(19) Gembrot $>$ Brot $>$ Subroto

(20) Kenur $>$ Nur $>$ Sunardi

(21) Pedhet $>$ Dhed $>$ Dhedi (Putranto)

Kanthong 'sack' got its bad connotation because it is often collocated with its attribute Bolong which means 'perforated, empty', and further to be associated with penniless and poverty. Kanthong Bolong is also used for Petruk's call name. In (22) to (25) below, the formal shortened forms with or without phonological change are given final sound or syllabic addition.

(22) Srinthil $>$ Sri $>$ Sri (Rejeki)

(23) Kampret $>$ Kam $>$ Sukamto

(24) Buta $>$ Bud $>$ Budi (Siswanto)

(25) Kuncung $>$ Kun $>$ Kuncoro

Principally, no similarity relation holds between form and meaning or referent of the nick names. In case there is, the relation is generally unintentional or accidental, and the naming creator is blessed by this coincidence.

The formal relation of the real and nick name can be between the acronym or abbreviation and the person's real name to which it stands for, as shown by (26) to (29) below:

(26) Tinuk > Trisnaning Nugraheni Kusumaratri

(27) Bendol $>$ Beny Dolo

(28) Ambrol > Amin Broto Legowo

(29) Kazet > Komarulzaman

In (28) the acronym is intentionally created to phonemically coincide with other Javanese words ambrol meaning 'collapse, broken down'. Example (29) is the way how the initial Roman alphabet names are pronounced by the Indonesian and Javanese, [ka] and [zet]. Finally, the nickname can be the syllabic permutation or metathesis of the real name, such as shown by (30) below:

(30) Dawir $>$ Wirda (Hayati)

\subsection{Semantic Relation Type}

In the Javanese community, the girl whose real name is Dian 'lamp', is often given nick name Senthir or Teplok which both have the same meaning with the real name. However, Dian expresses a more prestigious connotation because it is commonly used in literary style. On other hand, Senthir 'small traditional carosene lamp without flashlight' and Teplok 'traditional lamp with flash light' are common words used daily for referring to a simple lamp of the humble lower class economy people. In short, there is a synonymous relationship between the real name and the nickname.

\section{(31) Senthir > Dian (Retno Hapsari) \\ (32) Teplok > Dian (Retno Hapsari)}

The formal relation type between the real name and the nickname can be methonymic. Such as shown by (33) and (35):
(33) Sampak > Edi (Basuki)
(34) Gombloh > Edi (Sutrisno)
(35) Gentolet $>$ Bambang (Sarosa)

A Javanese person who has the real name $E d i$ 'good, beautiful' is possibly given nick name Sampak or Gombloh. This happens because his name is associated with a famous criminal at that time named Edi Sampak and a famous joker names Edi Gombloh. The nickname would be more unwavering if by any chance the owner's name has a similar physical appearance with those criminal and Joker. Similarly, the popularity of the Javanese Srimulat Group Joker Bambang Gentolet makes some Javanese people names Bambang to be jocularly called Gentolet.

Parents' name and their professions, especially fathers, in very rare cases, can also be used to nickname someone. This is specifically done by naughty children to call their friends in urban areas. For example, the Javanse person names Yuswadi 'long age' is summoned by his late father's name Jayus 'meaningless proper name'. Meanwhile, the person names Agus 'handsome' is called Tongseng 'dish prepared cabbage and lamb' because of his father profession as a Tongseng's seller.

\subsection{Similarity Relation Type}

In this type of relation, the nick names show various kinds of similarities with the physical, mental or behavioural characteristics of the person for whom the nick names are intended. For example, Petruk 'puppet clown character in the good side', Bagong 'puppet clown Petruk's younger brother', and Bengkring 'skinny' are nick names typically intended 
to label a certain person who consecutively has a tall and or long nose, big body, and thin or skinny body. Gandhen 'large mallet' is used for nicknaming a boy or man who has protruding fore and back head, like a large mallet. Meanwhile, Gendhon 'big headed caterpillar' is given to someone with a big head but a relatively small body. Everything concerned with the referents used by the Javanese speakers to create nick names and the reasons underlying their usage will be more profoundly discussed in the following sections.

\section{NICK NAME REFERENTS AND THEIR UNDERLYING USAGE}

A careful investigation finds that the referents used to create nick names in Javanese includes several categories, such as physical and mental condition; trade tool, house utensil, and others; shadow puppet and traditional art characters; artists and film characters; animal, its state and excrement; supranatural creature; profession; food; plant and its seed; Arabian names; and country. The following sections will consecutively discuss these referents and the reasoning behind their usage.

\subsection{Physical and Mental Condition}

The physical characteristics and mental condition of the person constitute the richest source of nicknaming in Javanese. The nick names such as Bengkring 'skinny' and Gepeng 'flat' is given for a thin or skinny person. Meanwhile, the big-bodied person will be called by names that refer to such conditions like Gendhut 'big', Gembrot 'fat', Gombloh 'big but loose', Jolodhong 'very big', Glondor 'big but difficult to move' and Gombong 'big but empty. The last two examples, also contain 'weak connotation'. For just the weak person, the Javanese people create several calls, like Kepleh 'powerless' and Klowor 'very weak'. For big-bodied and short people, the nick names like Cebol 'short', Konthet 'very short' are given. Physical conditions can also relate to certain body parts, such as Panjul 'protruded back head', Benjul 'protruded back and forehead', and Nonong 'protruded forehead' are applied to someone having portruded back, back and forehead, and forehead. Bothak 'bold' and Gundhul 'bold' are for the bold or hairless heads. Gadhul 'dirt between teeth', Mrongos 'protruded mouth' and Sronggot 'bad dental condition' is for every person who rarely brushes their teeth, and has an ugly mouth or dental conditions. Pesek 'flat nose' is given for a person with a flat nose. Tembong 'birthmark spot' is also used to nickname a person with such body characteristics. Kuncung 'tuft' is a nickname for a person named Kuncoro or whose front hair is like a tuft. A taboed human body part, Gamblis 'hairs near the anus' and Kopet 'excrement near anus' are both used to create a metonymical insulting call for any person who often talks impolitely or indecently.

Stupidity and madness are the most common mental condition for which nick names are created. Kemplu 'stupid', Koplo 'mad', Menyung 'mad', Bambung 'naughty, crazy' are Javanese nick names for a slow thinking, lower intelligence, or strange behaviour person. Plengeh 'easy to smile' is intended to summon an easy smiling person based on facial expression similarity.

\subsection{Trade Tool, House Utensil, and Others}

Gandhen 'big mallet' and Palu 'hammer' are used for nicknaming person with protruding back and fore- head', while Kenur 'string' is used to call the person whose real name is Sunardi 'big light'. Senthir 'traditional lamp', and Teplok 'traditional lamp with a flashlight' is insulting calls for a person named Dian. Cempluk and Bagor 'sack' are house utensils used for keeping salt and rice or cassava. With regards to nicknaming, these words are used to call fat boy or chubby girl. Finally, Gotri 'pellet' is used for nicknaming someone whose real name is Tri 'the third child'.

\subsection{Shadow Puppet and Traditional Art Character}

Although shadow puppet is nowadays no more a favourite performance for the Javanese younger generation to watch, this traditional art so deeply penetrates the Javanese culture that the shadow puppet characters and anything related to them is still massively used by the Javanese speakers to create metaphorical expressions. As such, It is not surprising if funny puppet characters which are mostly clowns constitute the most common source of referent for the nick names in Javanese. Those characters are Bagong, Petruk, Gareng, Limbuk, Cangik, Cakil, Griwa, Kanthong, etc. Bagong is a nickname for a person who has a big body, wide mouth, and big eyes; Petruk is a call for a long and thin person with a long nose, slow thinking, and someone who like to give command and direction by using his index finger; Gareng is commonly used to refer to a small person with or without bending hand, and limp; Limbuk is an insult call intended for any big and ugly stylish woman; Cangik is given for a tall and skinny woman with protruded lower mouth. Cakil is a jocular call for a person with many whims and protruded lower jaw; Griwa derived from Sugriwa, one of the ape troop leaders in Ramayana Epic, is a call for a man whose body is full of hairs; Kanthong (Bolong) is Petruk's other name for labelling any person of the same characteristics. 
Meanwhile, Javanese traditional art characters, such as Penthul, a funny character in Javanese mask dance is used to nickname a man with the same facial appearance.

\subsection{Artists and Film Characters}

It is still unknown whether a famous joker's name Doyok has physical or facial similarities with the traditional masked performance character, but through the artist popularity, this name is used to nickname some people based on physical resemblances. See the following (36) and (37):

(36) Doyok > Bambang Setyarso

(37) Doyok $>$ Hery Purwanto

Some Javanese children are nicknamed by characters found in clay doll film characters Suyadi's creation, such as Unyil and Cuplis. The naming is based on physical or behavioural characteristics. The popularity of heroic film characters, such as Rambo portrayed by Sylvester Stallone and Ohara by Pat Morita, has made Javanese people names Margono and Sugito be nicknamed using such characters merely because of their hobby to ride a big similar motorbike, and physical characteristics, bold, short body, and small eyes. Consider (38) and (39):

(38) Rambo > Margono

(39) Ohara $>$ Sugito

\subsection{Animal, Its State and Excrement}

There are a lot of animals to be used as the source of nick names. Among them are Cemeng 'kitty', Codot 'bat', Kebo 'buffalo', Kenthus 'frog', Coro 'cockroach', Celeng 'forrest pig', Gudhel 'young buffalo', etc. Physical and behavioural similarities are generally used as the basis of nicknaming. For example, Cemeng and Codot are respectively used for naming someone who has a facial appearance like kitty and bat. Kebo is intended to insult someone who has a big body and physical strength but slow thinking. Kenthus is given for an arrogant person like a frog which used blowing up its belly. Coro, Celeng and Gudhel are respectively for calling a thin person of having dirty appearance, fat body and dark skin, and a child with extraordinary physical strength.

Trondol, brindhil, Jambul and Jelitheng are derived from Javanese adjectives which consecutively mean 'featherless' (especially for chicken), 'featherless', 'crest' ( especially for bird), and 'black' (for cricket wings). These adjectives are very common to call a man or woman having no or very thin or curly hair, a man with straight front hair, and a person with very black skin. And finally, Srinthil which means 'goat droppings' is used to nickname a woman whose formal name or part of her formal name is Sri 'light'.

\subsection{Supranatural Creature}

Wicked supranatural creatures are also possible to use as the source of nickname creation. For example, Tuyul 'small bodily spirit' and Dhemit 'ghost' are respectively used to call a bold and small person, and person who appears and disappear quickly. Because of electronic cinema influence, some supranatural spirit film characters, such as Mak Lampir and Grandong, characters of "Misteri Gunung Merapi" (Mistery of Mount Merapi) are now found in the use of Javanese for referring a woman and a boy of the same behavioural characteristics as the ghost film characters (see artists and film characters section).

\subsection{Profession}

In the Javanese community, the person is also possible to be jocularly called by several professions which are considered illegal by the society members. Some of those professions are Copet 'pick pocket', Maling 'thief', and Gondhes 'thief'. Physical characteristics and behavioural similarities must be the reason for the naming. It is a lot of seller professions which relate to the merchandise being sold or delivered to be used as modifiers to specify the person's real names, but they never stand alone to function as nick names, such as Limun 'soda pop' in Hardjo Limun, Wedhus 'goat' in Paryono Wedhus, Koran 'news paper' in Suroto Koran, etc.

\subsection{Food}

Some unprestigious Javanese traditional foods, such as Cemplon 'sweet fried cassava ball', Gandhos 'cookies made of baked coconut grate', and Gembus 'food made of bean curd waste' are used to call Javanese person based on physical similarities or behaviours.

\subsection{Plant and Its Seed}

Kimpul and Gembolo both refer to 'calladium tuber'. These words are later derived for creating nick names to label a person of big and short body or chubby cheek. Meanwhile, Pongge 'durian seed' is used to nickname any individual whose head has the same appereance to such an object.

\subsection{Arabian Names}

Javanese rural people are formerly relatively rare to name their children in Arabic. The more common 
name them with Javanese names, such as Sunardi 'glorious light', Darminto 'eternal truth', Suwarno 'gold'. However, for making a surprise, their friends ironically call them by shortening and altering the vowel of the short-form names to equate them with Arabian names. So, Sunardi and Darminto are shortened first becoming Nur and Dir. Nur which accidentally means the same 'light' and Dir 'goodness' is later undergoing syllabic lengthening to become Kenur 'brick layer's string' and Kadir 'The Almighty'. There is certainly no semantic or similarity relation between the name and the person they refer to. For Sunardi shortening process see (20), and for Darminto see (40) below:

\section{(40) Kadir $>$ Dir $>$ Dar(minto)}

Possibly there is an ironic relationship between the Arabian names and the rural Javanese condition in the past time. However, now in more recent times, the use of Arabian names among the younger Javanese generation is increasing noticeably.

\subsection{Traditional sport}

Javanese community has a lot of traditional sports one of which is played using long two bamboo poles with footsteps for walking. So, the person will look much taller than the others when he uses this traditional device. The instrument is called Enggrang 'stilts'. Accordingly, the tall Javanese person is possibly given this word for his nickname.

\subsection{Country}

The success of Cameroon's soccer team several times entering the final round of the World Cup Championship makes the country's name very popular in Indonesia. The Javanese is the biggest Indonesian population gets the impact of this phenomenon. The naturalized name of the country Kamerun (English: Cameroon) is used metonymically by the Javanese to nickname a blackskinned Javanese child based on this physical similarity.

\section{CONCLUSION}

The existence of formal and informal speech situation dichotomy consequently causes the emergence of formal and informal names used by the speakers of any language for each situation. Concerning the informal name or commonly known as a nickname, this kind of name is used to summon or label any person either literally or ironically for implementing various speech functions (strengthening, insulting, offending, teasing, joking etc.) in informal or intimate occasions. As far as the nickname and real name or the owner's name relations are concerned, there are at least four relation types that hold between them, namely arbitrary relation, formal relation, semantic relation, and similarity relation type. Semantically, Javanese nick names denote various kinds of referents, such as physical and mental condition; trade tool, house utensil, and others; shadow puppet and traditional performance art characters; artists and film characters; animal, its state, and excrement; supranatural creature; profession; food; plant and its seed; Arabian names; traditional play and country. The referents are possibly related or ironically related with physical or behavioural characteristics, and the mental state of the owners of the nick names.

\section{REFERENCES}

[1] Hornby, A.S. 2010. Oxford Advanced Learner's

[2] Evans-Pritchard, E.E. "Nuer Modes of Address". Culture and Society (Dell Hymes (Ed.)). New York: Harper \& Row.

[3] Ervin-Tripp, S.M. 1972. "Sociolinguistic Rules of Address". Sociolinguistics. (J.B. Pride and Janet Holmes (Eds.)). Hardmondsworth: Penguin Books Ltd.

[4] Suhardi, R., I D. P. Wijana, H. A. Bakar, \& Soenarjo. 1985. Sistem Sapaan dalam Bahasa Jawa. Yogyakarta: Departemen Pendidikan dan Kebudayaan.

[5] Widodo, S. T. 2013. "Kostruksi Nama Orang Jawa: Studi Kasus Nama-nama Modern in Surakarta". Humaniora, Vol. 25, No.1. Pp. 8291. Fakultas Ilmu Budaya Universitas Gadjah Mada.

[6] Widodo, S. T. 2016. "Nama Diri Orang Jawa sebagai Bentuk Penguatan Karakter Budaya Etnik di Indonesia". Isu-Isu Mutakhir dalam Kajian Bahasa dan Sastra. Yogyakarta: Interlude.

[7] Sahayu, W. 2014. Nama Diri Masyarakat Jawa. Dissertation. Gadjah Mada University.

[8] Pyton, C. 1990. Address and The Semiotics of Social Relations: A Systemic-Functional Account of Address Forms and Practices in Australian English. Unpublished Doctoral Dissertation: University of Sydney.

[9] Starks, D., K. Taylor, and L. Willoughby. 2012. "Nick names in Australian Secondary Schools: Insight into Nick names and Adolescent Views of Self'. Names: A Journal of Onomastics. Routledge: Taylor \& Frabcis Groups. 
[10] Zaitzow, B. H., J. K. Skipper \& C. Bryant. "Nick Names of Female Felons". Names: A journal of Onomastics. Routledge: Taylor and Francis. Pp. 83-99.

[11] Wibowo, R. M. \& A. Retnaningsih. 2015. "Dinamika Bentuk-bentuk Sapaan sebagai Refleksi Sikap Berbahasa Masyarakat Indonesia". Humaniora. Vol 3. Oktober. Pp. 269-282. Fakultas Ilmu Budaya Universitas Gadjah Mada.

[12] Supardo, S. 1995. Sistem Sapaan dalam Bahasa Jawa Dialek Banyumas. Tesis S2 Program Pascasarjana Universitas Gadjah Mada.

[13] Sulistyowati, 2008. "Alternasi Sapaan Bahasa Jawa di Kraton Yogyakarta". Humaniora. Vol. 20. No2. Pp. 168-178. Fakultas Ilmu Budaya Universitas Gadjah Mada.

[15] Joss, M. 1962. The Five Clocks. Mouton Co.

[16] Hymes, D. 1974. Foundations in Sociolinguistics: An Etnographic Approach. Philadelpia University Press.

[17] Leech, G.N., 1983. Principle of Pragmatics. London: Longman.

[18] Wijana, I D. P. 1996. Dasar-dasar Pragmatik. Yogyakarta: Andi.

[19] Pradopo, R.D. 2012. Pengkajian Puisi. Yogyakarta: Gadjah Mada University Press.

[20] Uhlenbeck, E.M. 1982. Kajian Morfologi Bahasa Jawa. Jakarta: Djambatan.

\section{List of Javanese Nick Names in Alpabhetical Order}

Ambrol 'broken down'

Bagong 'clown with big body, mouth, and eyes in shadow puppet performance'

Bagor 'sack'

Bambung 'mad'

Bendol 'meaningless proper name'

Bengkring 'thin, skinny because of illness'

Benjul 'protruded back and forehead'

Brindhil 'bold or curly'

Buta 'giant'

Bothak 'bold'

Brindil 'featherless'
Cakil 'protruded lower jaw giant in shadow puppet performance'

Cangik 'thin and tall old woman character (Limbuk's mother) in shadow puppet performance'

Cebol 'big and short'

Celeng 'forrest pig'

Cemeng 'kitty, baby cat'

Cemplon 'sweet cassava fried ball'

Cibik 'meaningless proper name'

Codhot ' big bat'

Copet 'pick pocket'

Coro 'cockroach'

Cuplis 'Unyil's friend in clay doll film'

Dawir 'meaningless proper name'

Dhemit 'ghost'

Doyok 'Javanese masked dance character, or name of Indonesian famous joker'

Egrang 'stilts'

Gandhen 'big mallet'

Gandhos 'cookies made of cassava and coconut grate'

Gadhul 'dirt in between the teeth'

Gareng 'small bodied and limp clown character in puppet character'

Gamblis 'hairs near anus'

Gembolo 'calladium tuber'

Gembrot 'big, fat'

Gembus 'food made of bean curd waste'

Gendhon 'big headed catepillar'

Gendut 'big'

Gentolet 'name of famous joker'

Godhek 'meaningless proper name'

Gombong 'big but empty'

Gombloh 'big'

Gondhes 'thief'

Gotri 'pellet'

Grandong 'name of supranatural creature'

Griwa 'Ape troop leader in the Ramayana epic'

Gudel 'Young Buffalo' 
Gundhul 'shaved'

Ipul 'meaningles proper name'

Jambul 'crest'

Jayus 'meaningless personal name'

Jelitheng 'black in relation with cricket'

Jembluk 'big'

Jolodhong 'big body'

Kadek 'meaningless proper name'

Kadir 'an Arabic word mean almighty'

Kamerun 'name of an African country'

Kampret 'bat'

Kanthong (Bolong) 'perforated, empty sack, Petruk's other call name'

Kazet 'meaningless proper name'

Kemplu 'stupid'

Kening 'meaningless proper name'

Kenur 'string'

Kenthus 'frog'

Kepleh 'weak, broken wings or hands'

Kimpul 'calladium tuber'

Kopet 'excrement near anus'

Koplo 'mad'

Kotrek 'meaningless proper name'

Konthet 'short'

Kuncung 'tuft'

Lasiyuk 'meaningless proper name'

Lanjur 'meaningless proper name'

Limbuk 'big bodied woman clown in shadow puppet performance'

Maling 'thief'

Mak Lampir 'name of electronic cinema character'

Marjek 'meaningless proper name'

Menyung 'mad'

Mrongos 'protruded mouth'

Nonong 'protruded forehead'

Nandul 'meaningless proper name'

Nur 'an Arabic word means 'light',
Ohara 'heroic movie character potrayed by Pat Morita'

Palu 'hammer'

Panjul 'protruded back head'

Pego 'meaningless proper name'

Pesek 'flat nose'

Petruk 'Tall bodied and long nosed clown in shadow puppet performance'

Penthul 'Javanese masked dance character'

Plengeh 'easy smiling'

Pongge 'durian seed'

Rambo 'heroic movie character potrayed by Sylvester Stallonne'

Sampak 'name of a famous criminal'

Senthir 'small traditional lamp without flashlight'

Srinthil 'goat dropping'

Sronggot 'ugly teeth structure'

Sunir 'meaningless proper name'

Tembong 'birth mark spot'

Teplok 'traditional lamp with flash light'

Tinuk 'meaningless proper name'

Togog 'big bodied puppet character clown in the opposite/bad side of Gareng, Petruk, and Bagong'

Tongseng 'dish prepared with cabbage and lamb'

Trondhol 'featherless for chiken'

Tuyul 'small bodily spirit that obtains wealth for its master'

Unyil 'small boy character in clay doll film' 